\author{
MARTA COBEL-TOKARSKA* \\ Akademia Pedagogiki Specjalnej, Warszawa \\ ANNA POKRZYWA** \\ Akademia Pedagogiki Specjalnej, Warszawa \\ MAGDA PROKOPCZUK*** \\ Akademia Pedagogiki Specjalnej, Warszawa \\ https://doi.org/10.26485/PS/2018/67.4/3
}

\title{
PERSPEKTYWA MIEJSKA \\ W SOCJOLOGII ELŻBIETY TARKOWSKIEJ
}

\section{Streszczenie}

Artykuł ma na celu zaprezentowanie miejskiej perspektywy w pracy naukowej Elżbiety Tarkowskiej. Uczona, kojarzona głównie z socjologią czasu, kultury i ubóstwa, podejmowała wątki miejskie w swoich publikacjach, projektach badawczych oraz pracy dydaktycznej, tworząc specyficzny sposób patrzenia na miasto. Na podstawie analizy dorobku naukowego Elżbiety Tarkowskiej w artykule zostały opisane podejmowane przez nią wątki dotyczące przemian miasta w czasie, kultury miejskiej, jej multisensoryczności oraz stylów życia mieszkańców współczesnych miast. Perspektywa postrzegania zjawisk miejskich w kategoriach procesualności, czasoprzestrzeni, pamięci, mikro-zależności i lokalności może służyć badaczom społecznym jako narzędzie analityczne w badaniu miasta i miejskości.

Słowa kluczowe: Elżbieta Tarkowska, socjologia miasta, studia miejskie, miasto, kultura iwentu, wielozmysłowość

* Dr, Instytut Filozofii i Socjologii, Katedra Socjologii Kultury; e-mail: mcobelto@gmail.com

** Mgr, Instytut Filozofii i Socjologii, Zakład Metod Badań Społecznych i Ewaluacyjnych; e-mail: an.pokrzywa@gmail.com

*** Mgr, Instytut Filozofii i Socjologii, Katedra Socjologii Kultury; e-mail: magda.prokopczuk@gmail.com 
Obserwujemy wspótcześnie, w Polsce $i$ w skali globalnej, prawdziwa eksplozję nowych ruchów miejskich, oddolnych form zaangażowania $w$ problemy miasta, nowych inicjatyw lokalnych. Nowe formy miejskiego aktywizmu dotycza różnych aspektów życia mieszkańców: jakości życia, zagospodarowania przestrzeni publicznej, form spędzania czasu wolnego, relacji sąsiedzkich, transportu, wycinki drzew, lokalizacji pomników - a więc życia codziennego i sfery symbolicznej, spraw konkretnych i ogólnych ${ }^{1}$.

\section{WPROWADZENIE}

Niniejszy artykuł ma na celu przedstawienie socjologicznego spojrzenia Elżbiety Tarkowskiej na miasto. Czynimy to poprzez odnalezienie w jej twórczości, pracy naukowej i dydaktycznej wątków miejskich, które wpisują się we współczesną refleksję poświęconą społecznym i kulturowym uwarunkowaniom przestrzeni zurbanizowanych. Refleksja nad miastem, jego funkcjonowaniem, znaczeniem dla życia społecznego nie znajdowała się w centrum zainteresowań Elżbiety Tarkowskiej, dlatego też prezentowana perspektywa ma jedynie charakter fragmentaryczny, traktowana jest wyłącznie jako zespół propozycji i możliwych kierunków kontynuacji. Niemniej wątki miejskie pojawiające się w twórczości Elżbiety Tarkowskiej uważamy za warte prześledzenia i dalszej analizy.

Artykuł podzieliłyśmy na dwie zasadnicze części, które w sposób chronologiczny mają uporządkować problematykę. Pierwsza część poświęcona jest genezie zainteresowania Tarkowskiej miastem, miejskością i kulturą miejską. W tej części zaprezentowane zostały wątki miejskie poruszane w jej twórczości naukowej - w licznych książkach, artykułach i raportach badawczych. Starałyśmy się ukazać je kolejno, poprzez prezentację głównych zainteresowań naukowych Tarkowskiej - czasu, kultury i ubóstwa. W każdym z tych trzech obszarów tematyka miejska nie stanowi centralnego punktu rozważań, często traktowana jest wyłącznie jako sceneria do ukazania istotnych zjawisk i problemów społecznych lub wręcz pojawia się jedynie na marginesach. Uważamy natomiast, że bez szczegółowego prześledzenia drogi naukowej Tarkowskiej trudno będzie zrozumieć jej perspektywę patrzenia na miasto. W drugiej części omówiona została praktyka dydaktyczna Elżbiety Tarkowskiej. Jako jej uczennice, a na-

1 Cytat z wniosku o grant pt.: Spoleczny i kulturowy wymiar nowych inicjatyw miejskich na przykładzie dzielnicy Ochota: problemy społeczne, aktywność, kultura autorstwa Elżbiety Tarkowskiej, Anny Pokrzywy i Magdy Prokopczuk. 
stępnie współpracowniczki byłyśmy świadkami nasilenia jej zainteresowania miastem w ostatnich latach. Korzystając z notatek, relacji, rozmów, wspomnień ze spotkań, pragniemy zrekonstruować wpływ pracy dydaktycznej na ten proces. Zakończenie poświęcamy próbie osadzenia tej perspektywy w rozwijającej się dziedzinie studiów miejskich. Podsumowując dotychczasowe kierunki zainteresowań Tarkowskiej, podkreślamy, że pochylenie się nad przestrzenią miejską, jej funkcjonowaniem i doświadczeniem w sposób procesualny i rozumiejący może dostarczyć przydatnych narzędzi dla badaczy miejskich.

\section{MIASTO W TWÓRCZOŚCI NAUKOWEJ ELŻBIETY TARKOWSKIEJ}

Wybór poszczególnych fragmentów dorobku Elżbiety Tarkowskiej ma na celu ukazanie ciagłości i rozwoju w jej drodze naukowej, bez których trudno byłoby dostrzec implikacje miejskie. Jak pisze Nina Kraśko: „Pierwsze, na co musiałam zwrócić uwagę [czytając jej prace], to konsekwencja w rozwoju naukowym. [...] Kiedy patrzymy na podejmowane następnie tematy badawcze, mamy wrażenie, że były one realizacją kolejnych punktów tego planu. Co więcej, kończąc jeden etap, wygląda na to, jakby wiedziała, jak spożytkuje go w późniejszych pracach. Co ważne, plan ten nigdy nie oznaczał zawężenia pola zainteresowań" [Kraśko 2015: 55]. Zainteresowanie Elżbiety Tarkowskiej tematyką miejską traktujemy więc jako naturalną konsekwencję poprzednio podejmowanych zagadnień. W pracach poświęconych tematyce temporalnej, kulturze i ubóstwie odnajdujemy szereg wzmianek ukazujących możliwości rozumienia miasta i miejskości.

\section{„Żyjemy odcinkami czasu i odcinkami przestrzeni»"2 - o wymiarach organizacji życia społecznego}

Pierwszym naukowym zainteresowaniem Elżbiety Tarkowskiej był czas i jego doświadczanie. Skupiając się na nim, nie da się zapomnieć o drugim wymiarze, równie istotnie organizującym społeczną rzeczywistość, czyli o przestrzeni. Oba te wymiary wspólistniejąi wzajemnie na siebie wpływają. Wątek ten pojawiał się w twórczości Elżbiety Tarkowskiej, poczynając od wydanej w 1987 roku pierwszej książki poświęconej zagadnieniom temporalnym - Czas w społeczeństwie. Problemy, tradycje, kierunki badańn ${ }^{3}$. Tarkowska odnosiła się tam między innymi

\footnotetext{
2 Tarkowska 2012: 116.

3 Ważne jest tu także wieloletnie zainteresowanie Elżbiety Tarkowskiej klasykami francuskiej socjologii i antropologii oraz koncepcjami Stefana Czarnowskiego.
} 
do pojęcia czasu morfologiczno-ekologicznego Georges'a Gurvitcha, który odpowiada ,środowisku zewnętrznemu, przyrodniczemu i technicznemu. Uwzględniane są takie zjawiska, jak gęstość zaludnienia, ruch wieś-miasto, terytoria, regiony, państwa" [Tarkowska 1987: 108]. Dalej autorka rozwijała myśl, skupiając się na opozycji między różnymi typami zagospodarowania przestrzeni, pisząc: ,,jednym z istotnych wymiarów zróżnicowań orientacji temporalnych jest wymiar: wieś-miasto" [Tarkowska 1987: 154]. Elżbieta Tarkowska zauważyła, że odmienności „czasu kalendarzowego" i „czasu historycznego” robotnika i chłopa związane są z różnicami zawodowymi. Odwołując się do analiz Pierre'a Bourdieu i badań Rezsohéizy'ego przeprowadzonych w Peru, wskazała, że „różnice wieś-miasto to jednocześnie różnice między społecznością tradycyjną a społeczeństwem poddawanym procesom zmiany i modernizacji" [Tarkowska 1987: 154]. Także w późniejszych pracach kategoria „miasto-wieś” była dla niej jedną z podstawowych zmiennych różnicujących społeczeństwo choćby pod względem postaw wobec zjawisk i wartości, a co najważniejsze, jednym z istotnych uwarunkowań czasu społecznego i jego doświadczania.

W kolejnej książce, Czas wżyciu Polaków. Wyniki badań, hipotezy, impresje, wątek miasta pojawił się w kontekście przemian w przestrzeni mających metaforycznie „odwrócić bieg czasu”, czy może wyznaczyć bieg nowego. Wspominając o fenomenie kalendarzy rewolucyjnych, Tarkowska pisała: ,podobnie spektakularnym zjawiskiem związanym $\mathrm{z}$ rozpoczynaniem nowego czasu jest $\mathrm{w}$ okresie 1989/90 w krajach Europy Wschodniej zacieranie przeszłości przez niszczenie pomników, zmiany nazw miast, ulic itd." [Tarkowska 1992: 44]. Cytowana wypowiedź była zapowiedzią przyszłego zainteresowania autorki kwestią pamięci, a w interesującym nas obszarze miejskimi formami upamiętniania przeszłości, w szczególności muzeami i pomnikami.

Krzysztof Podemski, badacz i znawca tematyki podróżniczej, nazwał Elżbietę Tarkowską socjologiem/antropologiem przestrzeni, a ściślej ,czasoprzestrzeni”. W książce Socjologia podróży [Podemski 2004: 110] przytoczył cytat z jej artykułu: ,podróż to nie tylko pokonywanie pewnej drogi i zmiana miejsca w przestrzeni, to także powiązane z tym szczególne doświadczenie czasu" [Tarkowska 1995: 12]. Również w tekście Czas w kulturze współczesnej Elżbieta Tarkowska pisała: „Ponowoczesność z kolei charakteryzuje swoisty kryzys, wyrażający się w załamaniu dotychczasowego porządku czasowego; są to zjawiska takie jak: odrzucenie linearności i postępu, koniec przyszłości i wręcz czasu samego, wzrost zaś roli przestrzeni" [Tarkowska 1996: 131].

Redaktorki tomu Coś, które nadchodzi. Architektura XXI w. przeprowadziły rozmowę z Elżbietą Tarkowską, koncentrując się na kwestii czasu. Jednak na 
pytanie: „Wszystko to, o czym pani mówi, jest przedmiotem zainteresowania architektów, bo to, jak ludzie organizują sobie czas w różnych przestrzeniach, wpływa przecież na ich projekty. Mieszkanie kogoś, kto pracuje w domu, musi wyglądać inaczej niż osoby, która pracuje fizycznie, a w domu chciałaby po prostu odpoczaćc. Jak czas wiąże się z przestrzenią?" [Tarkowska 2012: 116], Elżbieta Tarkowska odpowiedziała: „Powinno się mówić o czasoprzestrzeni. Nasza epoka jest szalenie mobilna, zmienna w przestrzeni i czasie. Ale do czego to doprowadzi? Być może do tęsknoty za stałością. Na razie przemieszczamy się, by kolekcjonować wrażenia. Przestrzeń też jest pokawałkowana jak czas. Żyjemy odcinkami czasu i odcinkami przestrzeni" [Tarkowska 2012: 116].

Wydaje się, że kategoria czasu okazała się ważna dla wykształcenia specyficznego spojrzenia na miasto: perspektywy procesualnej, ujmującej miasto jako organizm dynamiczny, podlegający ciagłym zmianom. Opisując zjawiska miejskie oraz konkretne obiekty, Tarkowska poddawała je analizie diachronicznej, szukając sensów nie tylko w teraźniejszości, ale i w przeszłości, zarówno tej zapisanej w oficjalnej historii, jak i w pamięci ludzi - aktorów żyjących w miejskiej przestrzeni. W socjologii rozumiejącej, w której paradygmacie Elżbieta Tarkowska pracowała, aby dobrze pojąć zjawisko społeczne, należy ująć je w możliwie szerokim kontekście, odwołując się do ludzkiego doświadczenia. Pomimo fragmentaryczności wątków miejskich w pracach poświęconych tematyce temporalnej możemy zauważyć, że Tarkowska próbowała - łącząc perspektywę przeszłości i teraźniejszości - odczytywać wielość warstw skomplikowanego miejskiego palimpsestu.

\section{„Więcej kultury potrzebne socjologii miasta!”4 - w stronę wielozmysłowości i polifunkcyjności uczestnictwa w kulturze}

Próbując zrekonstruować perspektywę patrzenia na miasto Elżbiety Tarkowskiej, nie można pominąć kwestii kultury. Już w latach 90. XX wieku Elżbieta Tarkowska notowała na marginesie innych tematów swoje spostrzeżenia i refleksje na temat zmieniającej się gwałtownie miejskiej kultury, dostrzegając chociażby zjawisko „kolonizacji nocy”, które spowodowało wzrost aktywności ludności zamieszkałej w miastach w związku z rozwojem życia nocnego [Tarkowska 1999b].

Przełomem w jej myśleniu o mieście był natomiast początek XXI wieku i pojawienie się nowych koncepcji i kategorii w badaniach kultury. Elżbieta Tarkowska zamieściła w tomie Krótkich wykładów z socjologii przekrojowy

\footnotetext{
4 Wiadomość mailowa Elżbiety Tarkowskiej do Magdy Prokopczuk, 23.09.2015.
} 
tekst pod tytułem Socjologia kultury współczesnej [Tarkowska 2013b], w którym prezentuje nowe kierunki, prądy i idee w obszarze badania kultury. To właśnie począwszy od tego momentu, obserwujemy, że Elżbieta Tarkowska coraz więcej uwagi poświęcała miastu jako istocie kultury. Jako polski przykład cultural turn autorka wymieniła badania kultury miejskiej prowadzone dla NCK przez zespół socjologów, m.in. Wojciecha Bursztę, Barbarę Fatygę, Mirosława Pęczaka i Tomasza Szlendaka. Ich opublikowany w 2010 roku raport wskazywał, „że nowa rzeczywistość kulturowa polskich miast [...] wymaga nowego podejścia i nowych kategorii badawczych" [Tarkowska 2013b: 154]. Autorka wywodziła więc swoje rozważania o socjologii kultury współczesnej bezpośrednio z socjologii miasta, wskazując, że nowe narzędzia teoretyczne rodzą się z obserwacji świata społecznego, z badań terenowych, zwłaszcza prowadzonych we współczesnych polskich miastach.

Elżbieta Tarkowska miasto traktowała jako scenę, na której można obserwować spektakl powracającej mody, różnych form uczestnictwa w kulturze oraz wpływu kultury popularnej na wygląd i funkcje przestrzeni miejskiej. Dostrzegała fenomen „mody na miasto” i rozwijającej się turystyki miejskiej. Rzecz jasna, kluczowe jest tu nawiązanie do pamięci, nostalgii i różnych strategii „gry z przeszłością". W artykule Pamięć w kulturze teraźniejszości [Tarkowska $2016 a]^{5}$ pisała, że powroty i odtwarzania mody są niezwykle widoczne w przestrzeniach publicznych miast. Przytaczała wiele przykładów stylizacji barów, restauracji wykorzystujących ,świadectwa przemieszania nie tylko przeszłości z teraźniejszością, ale także autentyczności z fikcją, świata realnego i medialnego - różnych treści i wartości, przekształcanych w towar, zabawę i rozrywkę" [Tarkowska 2016a]. Wskazywała tym samym na zwrot w kulturze miejskiej ku polifunkcyjności i doświadczeniom zmysłowym.

Szczególnie użyteczna w tym kontekście wydała się autorce koncepcja „wielozmysłowej kultury iwentu” stworzona przez Tomasza Szlendaka [2010], znajdująca zastosowanie w opisie właściwie każdej aktywności kulturowej mieszkańców miast. Elżbieta Tarkowska, wykorzystując tę koncepcję, podkreślała, że współczesne uczestnictwo w kulturze opiera się głównie na udziale w iwentach, takich jak np. Noc Muzeów, festyny, parki tematyczne, inscenizacje historyczne, imitacje przeszłości czy zorganizowane spacery po cmentarzach. Pisała: „wszystko jest «na dotknięcie ręki», wszystko jest zabawą i gra, poszukiwaniem wrażeń i przyjemności” [Tarkowska 2016a]. Pokazywała zatem miasto jako

5 Pierwodruk: Tarkowska Elżbieta. 2012. Pamięć w kulturze teraźniejszości. W: Kultura jako pamięć. Posttradycjonalne znaczenie przeszłości, E. Hałas (red.), 17-42. Kraków: Nomos. 
miejsce, w którym dokonuje się „festynizacja kultury”. Co ważne, opisując te zjawiska, nie wartościowała przemian kultury współczesnej, traktowała je jako fakt społeczny, który powinien zostać uchwycony i opisany przez współczesnych badaczy kultury. Była przy tym świadoma, że owe przemiany kultury mogą być kontrowersyjne: „«Bawienie się przeszłością» w muzeach i innych «świątyniach pamięci», odejście od sacrum do profanum, od refleksyjności ku zmysłowości, przejście od przeszłości jako «źródła sensu» ku przeszłości będącej «atrakcyjnym i bogatym magazynem znaków, obrazów, figur stylistycznych» [Krajewski 2003, s. 206] jako nowa, alternatywna forma uczestnictwa w kulturze wywołuje niezrozumienie i krytykę z jednej strony, z drugiej - prowadzi do badawczego zainteresowania i refleksji nad charakterem przemian kultury współczesnej, w tym także struktur czasu" [Tarkowska 2016a].

Specyficzny kształt przejawów współczesnej kultury był dla Elżbiety Tarkowskiej efektem odejścia od refleksyjności właśnie ku multisensoryczności. Dostrzegając zachodzące zmiany, doceniała wielość perspektyw sensorycznych współcześnie rozwijanych w socjologii, interpretując takie doznania jako impulsy do działań więziotwórczych: „Wśród mnogości zachodzących zmian społecznych i kulturowych, jakie odnotowują badacze kultury, wyjątkowe znaczenie mają zmiany o charakterze długiego trwania, które Maryla Hopfinger nazywa «rekonfiguracjami komunikacji społecznej», obejmując tym mianem proces przejścia od kultury werbalnej, opartej na dominacji pisma i druku, do kultury audiowizualnej, skoncentrowanej na obrazie i dźwięku [Hopfinger 2010]. Ujmując to inaczej, chodzi o dominujący w kulturze odbiór poprzez zmysły wzroku i słuchu, poprzez oko i ucho, których istotną rolę w relacjach międzyludzkich opisał Georg Simmel w swej Socjologii zmystów [Simmel 2006]. Wielu badaczy kultury odsłania także rolę innych zmysłów, takich jak zapach czy smak. Można tu odwołać się do koncepcji kultury aromatyzacji Marka Krajewskiego [Krajewski 2003], do postulatu osmosocjologii, czyli socjologii zapachu Marka Szczepańskiego [Szczepański, Ślęzak-Tazbir 2008] czy do coraz liczniejszych prac zgłębiających kulturowe i społeczne funkcje zapachu [Hoffmann 2013; Prokopczuk 2014]" [Tarkowska 2014: 51].

Obserwując różne wydarzenia (jak na przykład lokalny festiwal zup na warszawskim Mokotowie) odbywające się w mieście, czy biorąc w nich udział, Elżbieta Tarkowska dostrzegała wyłaniający się nowy styl miejskiego życia - odradzanie się miejskich wspólnot w szczególnym kontekście wielozmysłowości. W artykule Kultura wielozmystowa: powrót do Kitowicza? [Tarkowska 2014] wspominała, że tego typu wydarzenia ,sygnalizują pewne charakterystyczne cechy współczesnej obyczajowości, czy szerzej, charakterystyczne rysy współ- 
czesnej kultury: widowiskowość, performatywność, uczestnictwo i zmysłowość. Są wyrazem ważnej zmiany kulturowej, jaka dokonała się współcześnie: tak zwanego zwrotu performatywnego (performative turn), polegającego na przejściu od orientacji na tekst i słowo pisane w stronę działania, przedstawiania, odtwarzania, zmysłowej inscenizacji [Bachmann-Medick 2012: 122]. Inscenizacje i rekonstrukcje, dostarczające głębokich przeżyć i oryginalnych doświadczeń uczestnikom i odbiorcom, porównywane w sposobie ich przeżywania do misteriów pasyjnych, angażujące zmysły i emocje, to nie tylko sposób rocznicowego upamiętniania ważnych wydarzeń z przeszłości, ale i coraz bardziej rozpowszechniony sposób atrakcyjnego spędzania czasu wolnego w przestrzeni publicznej, a także nierzadki element świętowania uroczystości prywatnych. $Z$ kolei różne formy biesiadowania, ucztowania, współczesny komensalizm czy jeszcze szerzej różne aspekty i funkcje konsumpcji kulinarnej to jeden z ważnych i również bardzo dziś popularnych impulsów dla wielokierunkowej działalności zbiorowej, angażującej uczestników na wiele różnych sposobów, stwarzającej płaszczyzny budowania i podtrzymywania więzi społecznych - rodzinnych, sąsiedzkich, przyjacielskich" [Tarkowska 2014: 47-50].

W powyższym cytacie widać specyfikę myślenia Elżbiety Tarkowskiej, dostrzegającej w przejawach miejskiego życia szersze prawidła funkcjonowania społeczeństwa. Zasygnalizowane wątki nie sąjednak rozwijane przez Tarkowską. Pomimo podkreślenia fenomenu miejskości, zwrotu w stronę polifunkcyjności i wielouderzeniowości współczesnej kultury brakuje w jej rozważaniach chociażby nawiązania do koncepcji Bourdieu, wskazującej wpływ kapitału kulturowego różnych grup czy klas społecznych na ich uczestnictwo w kulturze.

\section{Za kulisami wielkich ulic - miejskie enklawy biedy}

Trzecim obszarem zainteresowań Tarkowskiej była bieda. W tym kontekście autorka ukazuje miasto jako jedną ze scenerii, w których można obserwować różne przejawy ubóstwa. W jej licznych artykułach o biedzie wciąż pojawiała się opozycja wieś-miasto jako jeden z czynników determinujących odmienność sytuacji poszczególnych biednych. W 2002 roku w artykule Sto lat badań ubóstwa: kierunki zmian i nowe tematy wspominała o pionierskich badaniach Benjamina Seebohma Rowntree prowadzonych w Yorku, stanowiących ,prawdziwy kamień milowy w socjologicznym rozpoznaniu zjawisk ubóstwa oraz rozwoju metodologii i praktyki takich badań" [Tarkowska 2002: 180]. Sama skupiła się raczej na biedzie terenów defaworyzowanych, jak byłe pegeery czy szerzej - obszary wiejskie. Być może miała świadomość, że na ogół badacze więcej uwagi 
poświęcają miastu i jako badaczka ubóstwa starała się zrównoważyć wynikający stąd jednostronny obraz biedy. W 1999 roku pisała: ,,socjologia polska lat siedemdziesiątych i osiemdziesiątych bywała krytykowana za swój urbanocentryzm: za koncentrację na problematyce miejskiej, pomijanie natomiast wsi i problemów ludności wiejskiej. Odmienności życia i problemów wsi na ogół nie mieściły się w rozmaitych diagnozach i syntezach, operujących uogólnionym do poziomu całości społeczeństwa obrazem ludności miast i jej problemów. Miejscem właściwym problematyki wiejskiej była odrębna subdyscyplina - socjologia wsi [...]" [Tarkowska 1999a: 203].

Elżbieta Tarkowska zauważała jednak oblicze biedy miejskiej i wielkomiejskiej. Pisząc o okresie transformacji w porównaniu do lat PRL-u, stwierdzała: „W przeciwieństwie do tamtych czasów dzisiejsza bieda w Polsce jest dostrzegalna gołym okiem. W sensie dosłownym bieda «wyszła na ulicę» w postaci bezdomnych okupujących dworce kolejowe, żebraków na ulicach miast, starych ludzi przetrząsających pojemniki na śmieci w poszukiwaniu przydatnych jeszcze przedmiotów" [Tarkowska 2000a: 11]. W tym samym tekście wspominała o miejskich enklawach ubóstwa w Łodzi, Wrocławiu czy w aglomeracji górnośląskiej, opisanych przez takie badaczki, jak Wielisława Warzywoda-Kruszyńska, Danuta Zalewska czy Kazimiera Wódz. Doceniała też tzw. łódzką szkołę badań ubóstwa - jej bogaty dorobek badawczy skupiający się właśnie na wielkomiejskich enklawach ubóstwa, ich powstawaniu, mechanizmach funkcjonowania, feminizacji ubóstwa, dziedziczeniu biedy, czy oddziaływaniu „zubożałego sąsiedztwa na mieszkańców” [Tarkowska 2013a: 201]. Zauważała w Łodzi skutki upadku przemysłu włókienniczego, który spowodował największe bezrobocie w historii wielkich miast w Polsce, i nieznanej innym miastom skali bezdomności, zachowań kryminalnych, narkomanii. Wskazywała, że „bez wątpienia kluczową w dorobku łódzkiej szkoły badania ubóstwa jest «geografia ubóstwa», czy też «geografia nędzy», czyli pokazanie społeczności żyjących w miejskich skupiskach biedy i wykluczenia społecznego, gdzie dochodzi do nagromadzenia i nałożenia się na siebie wielu negatywnych zjawisk, ograniczających możliwości i wybory ludzi zamieszkujących te obszary - i konsekwencji zjawisk. Są to problemy znane z literatury jako procesy segregacji czy gettyzacji ludzi żyjących w biedzie" [Tarkowska 2013a: 202].

W tekście $O$ dawnej i obecnej biedzie w Polsce autorka wymieniła rozróżnienie na biedę wiejską i miejską jako pierwszą z ,takich spraw w dziejach biedy w Polsce, które wydają się istotne i inspirujące z perspektywy współczesności” [Tarkowska 2000b: 49]. O dawniejszej historii miejskiej biedy pisała następująco: „Rozwojowi miast na ziemiach polskich towarzyszył stały napływ najbiedniejszej ludności ze wsi i trwałe zjawisko miejskiej biedy. Do najbiedniejszych w mieście 
należały niektóre kategorie rzemieślników [...], handlarze, niewykwalifikowani pracownicy najemni, służba miejska i domowa, klientela szpitali i przytułków [Karpiński 1983], a także margines społeczny, czyli różni «hultaje, złoczyńcy, wszetecznice» - by odwołać się do tytułu jednej z książek [Kracik, Rożek 1986]. Wraz z rozwojem przemysłu nasilił się też proces napływu ludności najuboższej ze wsi do miast; na ziemiach polskich apogeum tych procesów przypadło na wiek XIX. «Wieś była odsączana stale przez rozwijający się przemysł miejski z najuboższego elementu, spośród którego mogłyby się kształtować najniższe warstwy społeczności wiejskiej» [Ihnatowicz, Mączak, Zientara, Żarnowski 1988: 518]. Według szacunków w dużych miastach, takich jak Warszawa, Łódź czy Wrocław, w drugiej połowie XIX w. żyło do kilku tysięcy nędzarzy. «Źródłem [ich] utrzymania bywała czasem nawet stała, ale bardzo nisko płatna praca zarobkowa. Zbieracze kości, szmat i rozmaitych odpadków w wielkich miastach należeli do mniej więcej ustabilizowanych w tej grupie. Mniej ustabilizowani byli ci, którzy utrzymywali się z doraźnych zarobków przy sezonowych robotach budowlanych, przy kolei, najmowali się do wyładunku towarów z barek wiślanych, wystawali w oznaczonych miejscach w mieście (np. w Warszawie koło kolumny Zygmunta i przy Pomniku Kopernika) w oczekiwaniu na jakiekolwiek zajęcie» [Ihnatowicz, Mączak, Zientara, Żarnowski 1988: 514]" [Tarkowska 2000b: 50-51]. Dalej zwracała uwagę, iż sytuacja zmieniła się z czasem, i ,[o]becna bieda w największym stopniu dotyczy wsi i małych miasteczek, w najmniejszym zaś zakresie - dużych miast" [Tarkowska 2000b: 57-58].

Analizując kategorie teoretyczne przydatne w badaniu współczesnej biedy, Elżbieta Tarkowska zwracała uwagę między innymi na koncepcję izolacji społecznej (social isolation) Williama J. Wilsona, jako ,pozwalając[a] na uwzględnienie cech kulturowych [...] istotnych dla zrozumienia zachowań mieszkańców badanych przez niego miejskich skupisk biedy. Ma ona jednocześnie wyrażać, że [...] specyficzna kultura getta ubóstwa jest «odpowiedzią na strukturalne przymusy i ograniczone możliwości» [Wilson 1987: 137]" [Tarkowska 2000a: 23]. W myśli tej uwydatnia się charakterystyczny model pracy i styl badań prowadzonych przez Tarkowską, która korzystając z metodologii jakościowej, skupiała się na kulturowym aspekcie ubóstwa.

\section{Praca dydaktyczna}

Od 2007 roku Elżbieta Tarkowska pracowała w Instytucie Filozofii i Socjologii Akademii Pedagogiki Specjalnej. Wzrost zainteresowania Tarkowskiej miastem widoczny był w jej pracy dydaktycznej, w której coraz chętniej podejmowała 
miejskie zagadnienia. Dla przykładu, próbując pokazać studentom, że badania kultury osadzone są zawsze w konkretnej rzeczywistości, wplatała do swoich zajęć (wykładów z socjologii kultury, socjologii moralności i obyczaju oraz seminariów dyplomowych) wątki zaczerpnięte wprost z socjologii miasta, między innymi hasło „rozwój miast” - jako istotny czynnik wpływający na współczesną kulturę, stanowiący o jej ważności. Podczas zajęć pochylała się nad zagadnieniami dotyczącymi cech współczesnego uczestnictwa w kulturze miejskiej, typów aktywności kulturalnej czy procesu „deinstytucjonalizacji” kultury w miastach. Zwracała uwagę na ważną rolę centrów handlowych, które skupiają w sobie najważniejsze trendy i liczne role, przejęte od innych instytucji (tematykę tę kontynuowała także podczas wykładów na temat kultury konsumpcyjnej oraz czasu wolnego). Pokazywała zjawiska negatywne: wycofanie się z życia w kulturze najuboższych i średniego pokolenia, wykluczenie, niedostateczną dbałość o edukację. Podsumowaniem najnowszych badań nad kulturą miejską miałoby być hasło „wybucha supernowa kultury”, a także nieustające podkreślanie jej wielkich przemian.

W roku akademickim 2015/2016 profesor Elżbieta Tarkowska prowadziła również odrębny wykład z przedmiotu socjologia miasta. Sylabus do przedmiotu dostarcza informacji o tym, które tematy z ogromnego obszaru socjologii miasta wydawały się jej na tyle ważne, by warto umieścić je w podstawowym kursie. Bardzo ważne miejsce zajmowały w nim zagadnienia związane bezpośrednio z kultura, sztuka, pamięcią; można także zauważyć nacisk na lokalny, środkowo- $\mathrm{i}$ wschodnioeuropejski kontekst w wykładzie poświęconym miastom socjalistycznym budowanym według wzorów obowiązujących w ZSRR. Elżbieta Tarkowska nawiązała także do kolejnego podstawowego obszaru swoich badań, jeden z wykładów poświęcając miejskim enklawom ubóstwa. Zwracała także uwagę na rozwój antropologii miasta, zresztą wielu studentów piszących prace o mieście korzystało z antropologicznych narzędzi i kategorii analitycznych.

Analizując wątki miejskie w działalności dydaktycznej Elżbiety Tarkowskiej, warto zauważyć, że mamy tu do czynienia z mechanizmem sprzężenia zwrotnego i wzajemnej inspiracji w relacji mistrz-uczeń. Studenci, którzy na pierwszym roku studiów uczęszczali na jej wykłady, często trafiali na prowadzone przez nią seminarium magisterskie, gdzie również dominowała szeroko rozumiana socjologia kultury. Profesor pozostawiała studentom swobodę w wyborze tematu przyszłej pracy dyplomowej, dzięki czemu mogła zauważyć sygnalizowane coraz częściej ich zainteresowanie socjologią miasta. Wynikiem tej wspólnej pracy były teksty oparte na socjologicznych i antropologicznych analizach, opisujące 
współczesne miasto - przede wszystkim Warszawę. Studenci pochylali się nad tematami z zakresu życia codziennego, pokazując różnorodne procesy społeczne, opisując mieszkańców miast $\mathrm{i}$ ich relacje w przestrzeni miejskiej. Prace studentów pisane pod kierunkiem ${ }^{6}$ Elżbiety Tarkowskiej opublikowane zostały w książce Miasto na dyplomach. Szkoła profesor Elżbiety Tarkowskiej [Cobel-Tokarska, Pokrzywa, Prokopczuk 2017].

Cytowane przez studentów teorie i koncepcje odzwierciedlają poszczególne obszary zainteresowań Elżbiety Tarkowskiej. Zaczynając od obszaru socjologii czasu, najbardziej uwidacznia się podejście ewolucyjne, ujmujące procesy i zjawiska miejskie. Wielokrotnie jej uczniowie, opisując znaczące przemiany przestrzeni miejskiej, wzbogacali je opisem historii miejsc i osobistymi wspomnieniami rozmówców. W ten sposób powstawały społeczne historie miejsc - w ramach paradygmatu socjologii humanistycznej - opowiedziane z uwzględnieniem głosów aktorów społecznych związanych z obiektem. W kontekstach kultury opisywanej w miejskiej scenerii główną rolę odgrywały wątki kultury konsumpcyjnej, zagadnienie stylów życia, przedstawione chociażby na przykładzie nowej metropolitalnej klasy średniej, budującej swoją tożsamość na intensywnej i precyzyjnie określonej konsumpcji. Kategoria stylu życia przenikała się z socjologią codzienności, studenci opisywali przemiany kultury w zakresie życia codziennego. Najskromniej w pracach studenckich reprezentowana była socjologia ubóstwa, ograniczona jedynie do miejskiej kategorii working poor i segmentacji przestrzennej.

Jednym z ostatnich przedsięwzięć naukowych Elżbiety Tarkowskiej były badania zatytułowane Społeczny i kulturowy wymiar nowych inicjatyw miejskich na przyktadzie dzielnicy Ochota: problemy społeczne, aktywność, kultura, przeprowadzone w zespole badawczym, nazywane ,grantem ochockim”. Zdając sobie

${ }^{6}$ Kacper Kożuchowski, Warszawska plaża Poniatówka dawniej i dziś; Monika Wróblewska, Stadion Narodowy jako epicentrum kultury; Anna Pokrzywa, Razem, obok siebie czy tylko inaczej? Analiza dawnych $i$ wspótczesnych relacji sasiedzkich $w$ Warszawie; Arkadiusz Jaroszewski, „Lemingi” z Miasteczka Wilanów; Katarzyna Tomaszewska, Praca w galerii handlowej. Elementy instytucji totalnej; Aneta Smaga, Galeria handlowa jako instytucja kultury; Magda Prokopczuk, Osmosocjologiczna mapa miasta; Aleksandra Koziar, „Zakochaj się w Warszawie”- wizerunek miasta. Większość prac dotyczy Warszawy.

7 Były to badania eksploracyjne, prowadzone w warszawskiej dzielnicy Ochota, gdzie znajduje się Akademia Pedagogiki Specjalnej, w której Elżbieta Tarkowska przez lata była Dyrektorem Instytutu Filozofii i Socjologii oraz Kierownikiem Katedry Socjologii Kultury. Efektem pierwszego i niestety ostatniego etapu badań, przeprowadzonych z autorkami niniejszego artykułu, Anną Pokrzywą i Magdą Prokopczuk, był ponad 70-stronicowy raport zatytułowany Społeczny i kulturowy wymiar nowych inicjatyw miejskich na przykładzie dzielnicy Ochota: problemy spo- 
sprawę z tego, jak istotne jest dla socjologa dotykanie rzeczywistości, chciała zbliżyć Instytut Filozofii i Socjologii Akademii Pedagogiki Specjalnej w Warszawie do bezpośredniego sąsiedztwa uczelni, a w przyszłości stworzyć pole dla szerszych badań dzielnicy. Pokazywała tym samym, że tematyka miejska łączy się nierozerwalnie z innymi dziedzinami życia społecznego. Elżbietę Tarkowską szczególnie interesowała tu tematyka problemów społecznych, rozumianych ,,po pierwsze, w sposób charakterystyczny dla podejścia socjologicznego, czyli jako warunki lub zachowania, które są postrzegane jako zagrożenie, jako odstępstwo od przyjętych standardów, któremu w jakiś sposób można by zaradzić [Frysztacki 2009]. Po drugie, problemy społeczne ujmujemy tak szeroko, jak widzą je nasi badani - jako różne sprawy do załatwienia, zagrożenia, trudności rozmaitej natury, różnych kategorii mieszkańców. Przeprowadzone wywiady dostarczają wielu przykładów tak właśnie szeroko rozumianego terminu, nie ograniczonego do problemów społecznych, lecz obejmującego także wszelkie inne kwestie, na przykład komunikacyjne, nadmiaru samochodów i in." [Pokrzywa, Prokopczuk, Tarkowska 2017: 56]. Mimo że Tarkowska w projekcie odpowiadała głównie za badanie problemów społecznych na Ochocie, jej ciekawość wzbudzały także inne zagadnienia. Historia dzielnicy, aktywność społeczna mieszkańców, sposoby spędzania przez nich czasu wolnego i tworzenie wspólnot lokalnych, miejsca kultury i nie-miejsca były wątkami, które postrzegała jako niezwykle interesujące dla socjologów i badaczy miasta.

\section{PERSPEKTYWA MIEJSKA - PRÓBA SYSTEMATYZACJI I PODSUMOWANIA}

Sposób patrzenia na miasto Elżbiety Tarkowskiej charakteryzował się dostrzeganiem mikrozależności i lokalności w przestrzeniach zurbanizowanych. Prezentowana perspektywa opiera się w znacznej mierze na durkheimowskiej tradycji traktowania przestrzeni jako istotnej kategorii do wyrażenia kolektywnych znaczeń będących wypadkową indywidualnych konstruktów [Majer 2010: 44]. Badanie sposobów doświadczania, funkcjonowania i zmian miasta możliwe jest chociażby poprzez zaproponowaną powyżej perspektywę procesualną, która zakłada ujmowanie różnych zjawisk w sposób diachroniczny i przyczynowo-skutkowy.

teczne, aktywność, kultura [Pokrzywa, Prokopczuk, Tarkowska 2017], którego skróconą wersję opublikowałyśmy w książce Miasto na dyplomach; fragmenty raportu ukazały się także w piśmie „Kultura i Społeczeństwo” 4/2016. 
Można dostrzec konsekwencję badaczki patrzącej na miasto podobnie jak na inne obszary swoich zainteresowań: poprzez paradygmat socjologii rozumiejącej. Jeśli miałybyśmy sytuować jej perspektywę w odniesieniu do istniejących szkół socjologii miasta, z pewnością mieści się ona w obrębie szkół kulturalistycznych i humanistycznych [Jałowiecki, Szczepański 2002: 21-41]. Zarówno poglądy Floriana Znanieckiego, który przestrzeń miejską rozumiał poprzez ludzkie doświadczenia, i badając miasto kierował się wskazaniem współczynnika humanistycznego, jak i badania przedstawicieli „szkół humanistycznych”, do których Bohdan Jałowiecki i Marek Szczepański włączają przede wszystkim socjologów życia codziennego, znajdują swoje odbicie w sposobie patrzenia na miasto Tarkowskiej. Jej perspektywa często pomija przy tym istotne sfery makrospołeczne i makrogospodarcze, stanowiące bezsprzeczne wyzwania dla współczesnych miast $^{8}$. A zatem można przyjąć, że szkoły ekologiczne, neoekologiczne i makrostrukturalne nie do końca wpisywały się w myślenie Tarkowskiej. Co ważne, Jałowiecki i Szczepański, dokonując ogólnej typologii szkół socjologii miasta, wskazują, iż oba ujęcia mają swoje słabości i osiągnięcia. Pomijając orientację ekologiczną, makrospołeczna, łatwo stracić z oczu całości społeczne, większe struktury, procesy zachodzace na terenie miasta. Jest to cena za indywidualizm metodologiczny i poznawczy oraz preferowanie badań jakościowych. Tarkowska szukała w miastach lokalności, jej spojrzenie nosi wyraźny rys antropologiczny. Próbą ucieczki od jednostronności takiej optyki może być jej zainteresowanie większymi całościami społecznymi, na przykład ruchami miejskimi, i próba wpisywania obserwowanych zjawisk w szersze, powszechne procesy społeczne, choćby te opisywane przez Tomasza Szlendaka.

Jeśli chodzi o najnowsze trendy socjologii miasta, sądzimy, że bliskie autorce było podejście Benjamina Barbera, entuzjasty miast, którego chętnie cytowała. W raporcie z badań Ochoty przywoływała jego słowa: „Miasta dużo lepiej odzwierciedlają dzisiejszy świat niż państwa” [Barber 2013]; oraz: „Państwa toczą wojny, natomiast miasta próbują współpracować” [Barber 2014: 123]. Wydaje się to dowodem na to, iż dostrzegała znaczenie miast nie tylko w skali ludzkiego doświadczenia, ale także w skali makrospołecznej. Jak pisała: „Socjologowie wskazują na wyjątkowy charakter współczesnych miast, w których jak w soczewce widać najważniejsze zjawiska i problemy współczesności [...]. Warto więc i trzeba badać zjawiska miejskie" [Pokrzywa, Prokopczuk, Tarkowska 2017: 34-35].

8 Wpływ tej perspektywy widać szczególnie w pracach jej uczniów, którzy najchętniej skupiali się na monograficznych opisach pojedynczych obiektów, stosując w badaniach metody jakościowe. 
Na koniec chciałybyśmy zaznaczyć, że celem artykułu nie jest uczynienie z Elżbiety Tarkowskiej socjologa miasta, lecz przedstawienie nowego, rodzącego się dopiero pola jej zainteresowań i badań w kontekście całości jej dorobku. Pole to jest rzecz jasna rozpoznane wyrywkowo, fragmentarycznie, wydaje nam się jednak, że wielość zasygnalizowanych wątków zasługuje na prześledzenie, utrwalenie i uwagę badaczy społecznych, dla których ta perspektywa może okazać się inspirująca.

\section{BIBLIOGRAFIA}

Augé Marc. 2010. Nie-miejsca. Wprowadzenie do antropologii hipernowoczesności. Warszawa: PWN.

Bachmann-Medick Doris. 2012. Cultural turns: nowe kierunki w naukach o kulturze. Warszawa: Oficyna Naukowa.

Barber Benjamin. 2013. „Państwa umierają, miasta nas zbawią. Z Benjaminem Barberem rozmawia Katarzyna Wężyk". Gazeta Wyborcza, 12-13.10.2013.

Barber Benjamin. 2014. Burmistrzowie rządzą światem. W: Miasto na żądanie. Aktywizm, polityki miejskie, doświadczenia, Ł. Bukowiecki, M. Obarska, X. Stańczyk (red.), 119-123. Warszawa: WUW.

Bogunia-Borowska Małgorzata, Piotr Sztompka (red.). 2008. Socjologia codzienności. Kraków: Znak.

Burszta Wojciech J. i in. 2010. Kultura miejska w Polsce z perspektywy interdyscyplinarnych badań jakościowych. Warszawa: Narodowe Centrum Kultury.

Cobel-Tokarska Marta, Anna Pokrzywa, Magda Prokopczuk (red.). 2017. Miasto na dyplomach. Szkoła profesor Elżbiety Tarkowskiej. Warszawa: APS.

Dymnicka Malgorzata. 2013. Przestrzeń publiczna a przemiany miasta. Warszawa: Scholar.

Fatyga Barbara. 2015. Kilka uwag o doświadczaniu czasu, dziecięcej ciekawości i nauce. W: Socjologia czasu, kultury i ubóstwa, K. Górniak, T. Kanasz, B. Pasamonik, J. Zalewska (red.), 149-154. Warszawa: APS.

Florida Richard. 2010. Narodziny klasy kreatywnej. Warszawa: Narodowe Centrum Kultury.

Frysztacki Krzysztof. 2009. Socjologia problemów społecznych. Warszawa: Scholar.

Harvey David. 2012. Bunt miast: Prawo do miasta i miejska rewolucji. Warszawa: Fundacja Bęc Zmiana.

Hoffmann Beata. 2013. Perfumy. Uwarunkowania kulturowo-społeczne. Kraków: Impuls.

Hopfinger Maryla. 2010. Literatura i media. Po 1989 roku. Warszawa: Oficyna Naukowa.

Ihnatowicz Ireneusz, Antoni Mączak, Benedykt Zientara, Janusz Żarnowski. 1988. Spoteczeństwo polskie od X do XX wieku. Warszawa: KiW.

Jałowiecki Bohdan, Marek Szczepański. 2002. Miasto i przestrzeń w perspektywie socjologicznej. Warszawa: Scholar.

Jawłowska Aldona, Edmund Mokrzycki. 1978. Style życia a przemiany struktury społecznej. Propozycja typologii historyczno-socjologicznej. W: Styl życia: przemiany we współczesnej Polsce, A. Siciński (red.), 182-228. Warszawa: PWN.

Karpiński Andrzej. 1983. Pauperes. O mieszkańcach Warszawy XVI i XVII wieku. Warszawa: PWN. 
Kłoskowska Antonina. 1972. Społeczne ramy kultury. Warszawa: PWN.

Kracik Jan, Michał Rożek. 1986. Hultaje, złoczyńcy, wszetecznice w dawnym Krakowie. O marginesie społecznym XVI-XVIII wieku. Kraków: Wydawnictwo Literackie.

Krajewski Marek. 2003. Kultury kultury popularnej. Poznań: WUAM.

Krajewski Marek. 2012. Niewidzialne miasto. Warszawa: Fundacja Bęc Zmiana.

Kraśko Nina. 2015. Elżbieta Tarkowska w społecznej roli uczonej. W: Socjologia czasu, kultury i ubóstwa, K. Górniak, T. Kanasz, B. Pasamonik, J. Zalewska (red.), 40-57. Warszawa: APS.

Kubicki Pawel. 2011. „Nowi mieszczanie - nowi aktorzy na miejskiej scenie”. Przeglad Socjologiczny 2-3(60): 203-227.

Majer Andrzej. 2010. Socjologia i przestrzeń miejska. Warszawa: PWN.

Makowski Grzegorz. 2004. Światynia konsumpcji. Geneza i społeczne znaczenie centrum handlowego. Warszawa: Wydawnictwo Trio.

Nijakowski Lech. 2006. Domeny symboliczne. Warszawa: Scholar.

Pawełczyńska Anna, Elżbieta Tarkowska. 1987. Life styles of individuals and families in Polish cities. W: Ways of life in Finland and Poland, J.P. Roos, A. Siciński (eds.), 89-110. Aldershot: Avebury.

Podemski Krzysztof. 2004. Socjologia podróży. Poznań: WUAM.

Pokrzywa Anna, Magda Prokopczuk, Elżbieta Tarkowska. 2017. Społeczny i kulturowy wymiar nowych inicjatyw miejskich na przykładzie dzielnicy Ochota: problemy społeczne, aktywność, kultura. W: Miasto na dyplomach. Szkoła profesor Elżbiety Tarkowskiej, M. Cobel-Tokarska, A. Pokrzywa, M. Prokopczuk (red.), 34-73. Warszawa: APS.

Prokopczuk Magda. 2014. Kultura czy natura? O osmologicznych konsekwencjach strategii dezodoryzacji, praca magisterska obroniona w Akademii Pedagogiki Specjalnej, maszynopis.

Simmel Georg. 2006. Most $i$ drzwi. Wybór esejów. Warszawa: Oficyna Naukowa.

Socjologia to coś więcej niż zawód... Rozmowa z profesor Elżbietą Tarkowską. 2015. W: Socjologia czasu, kultury i ubóstwa, K. Górniak, T. Kanasz, B. Pasamonik, J. Zalewska (red.), Warszawa: APS.

Sułkowski Bogusław. 2011. „«Społeczne ramy kultury» czterdzieści lat później. Pięć modeli komunikacji kulturowej”. Kultura i Społeczeństwo 2-3(55): 4-32.

Szczepański Marek, Weronika Ślęzak-Tazbir. 2008. „Miejskie pachnidło. Fragmentacja i prywatyzacja przestrzeni w perspektywie osmologicznej". Studia Regionalne i Lokalne 2(32): 18-40.

Szlendak Tomasz. 2010. „Wielozmysłowa kultura iwentu. Skąd się wzięła, czym się objawia i jak w jej ramach oceniać dobra kultury?”. Kultura Wspótczesna 4(66): 80-97.

Szlendak Tomasz, Krzysztof Olechnicki. 2017. Nowe praktyki kulturowe Polaków. Megaceremoniaty i subświaty. Warszawa: PWN.

Tarkowska Elżbieta. 1987. Czas w spoleczeństwie. Problemy, tradycje, kierunki badań. Wrocław: Ossolineum.

Tarkowska Elżbieta. 1992. Czas w życiu Polaków. Wyniki badań, hipotezy, impresje. Warszawa: Wydawnictwo IFiS PAN.

Tarkowska Elżbieta. 1995. „Czas podróży, włóczęgi, wędrówki”. Res Publica Nowa 7-8(82-83): $12-14$

Tarkowska Elżbieta. 1996. „Czas w kulturze współczesnej”. Kultura i Społeczeństwo 4(40): 131-134.

Tarkowska Elżbieta. 1999a. „Nie tylko socjologia wsi”. Kultura i Społeczeństwo 2(43): 203-205.

Tarkowska Elżbieta. 1999b. Spór o niedzielę w perspektywie globalnych przemian kulturowych. W: Religia i kultura w globalizującym się świecie, M. Kempny, G. Woroniecka (red.), 112-120. Kraków: Nomos. 
Tarkowska Elżbieta. 2000a. Bieda, historia i kultura. W: Zrozumieć biednego. O dawnej i obecnej biedzie w Polsce, E. Tarkowska (red.), 9-25. Warszawa: IFiS PAN.

Tarkowska Elżbieta. 2000b. O dawnej i obecnej biedzie w Polsce. W: Zrozumieć biednego. O dawnej i obecnej biedzie w Polsce, E. Tarkowska (red.), 49-60. Warszawa: IFiS PAN.

Tarkowska Elżbieta. 2002. „Sto lat badań ubóstwa: kierunki zmian i nowe tematy”. Kultura i Społeczeństwo 4(46): 179-188.

Tarkowska Elżbieta. 2011. Czas i pamięć w kulturze i społeczeństwie. W: Krótkie wykłady z socjologii, A. Firkowska-Mankiewicz, T. Kanasz, E. Tarkowska (red.), 29-44. Warszawa: APS.

Tarkowska Elżbieta. 2012. Przyszłość raczej teraz. W: Coś, które nadchodzi. Architektura XXI w., B. Świątkowska (red.), 114-116. Warszawa: Fundacja Bęc-Zmiana.

Tarkowska Elżbieta. 2013a. „Łódzka szkoła badań ubóstwa”. Kultura i Społeczeństwo 4(57): 199-206.

Tarkowska Elżbieta. 2013b. Socjologia kultury współczesnej. W: Krótkie wykłady z socjologii, A. Firkowska-Mankiewicz, T. Kanasz, E. Tarkowska (red.), 152-171. Warszawa: APS.

Tarkowska Elżbieta. 2014. „Kultura wielozmysłowa: powrót do Kitowicza?”. Societas/Communitas 1(58): 47-58.

Tarkowska Elżbieta. 2016a. „Pamięć w kulturze teraźniejszości”. Kultura i Społeczeństwo 4(60): 133.

Tarkowska Elżbieta. 2016b. „Życie codzienne jako przedmiot nie tylko najnowszej socjologii. Na marginesie Socjologii Codzienności”. Kultura i Społeczeństwo 4(60): 97-98.

Wilson William J. 1987. The truly disadvantaged. The inner city, the underclass, and public policy. Chicago: University of Chicago Press.

Zalewska Joanna. 2015. Kategoria stylów życia w twórczości naukowej Elżbiety Tarkowskiej. W: Socjologia czasu, kultury i ubóstwa, K. Górniak, T. Kanasz, B. Pasamonik, J. Zalewska (red.), 157-167. Warszawa: APS

Marta Cobel-Tokarska

Anna Pokrzywa

Magda Prokopczuk

\section{THE URBAN PERSPECTIVE IN ELŻBIETA TARKOWSKA'S SOCIOLOGY}

\section{Summary}

This article aims to show the urban perspective in Elżbieta Tarkowska's academic work. The scientist commonly associated with time, culture and poverty, undertook city-related topics in numerous publications, research and her didactic work. The result is a unique way of looking at the city. Based on her publications, in the article, we show points related to space-time, the transformation of the city in time, urban culture, its multi-sensuality and the lifestyles of the inhabitants of modern cities. Elżbieta Tarkowska's urban perspective connected with trajectory, space-time, memory, micro-reliances and locality can be useful for other social researchers as a way to analyse cities and urban life.

Keywords: Elżbieta Tarkowska, sociology of the city, urban sociology, urban studies, city, culture of event, multi-sensuality 